NOTES ON THE ACRIDIDAE OF NEW ENGLAND.-II.-TRYXALINAE.- III.

BY ALbERT P. MORSE, WELlesley, MASS.

Pseudopomala brachyptera (cont.).

Habits, etc. This peculiar locust is not uncommon locally on the coarser grasses found in waste lands, especially upon a species of bunch-grass (Andropogon scoparius) everywhere abundant. I have taken it also on beach-grass at Provincetown, and upon timothy. Though a good leaper and fairly active it is not shy and seeks safety in attempting to escape observation by sidling around the grass-stems rather than by active retreat. I once saw a long-winged female fly several feet, proving that with the possession of the means came the power of flying. Its sluggish habits, however, in connection with its linear form, render it less likely to attract the attention of its enemies, and to the biologist it is perhaps the most interesting of our locusts on that account. It must be seen in the living state to have its full beauty appreciated. The singular, almost grotesque, yet graceful form interests even the casual observer, and its coloration of lilaceous drab, giving it almost the appearance of being clothed with a delicate bloom, pleases the most fastidious eye.

I have taken young specimens at various times in June and July and adults from July ro to Sept. 3. It is likely to be met with, however, a week earlier and some time later in the season. About 150 specimens, chiefly collected in person, are from Fryeburg, Me.; Florence (S. W. Denton), Provincetown, Sherborn, Sudbury, Wellesley, Winchendon, and West Chop, M. V., Mass. ; Canaan, North Haven, and Thompson, Conn. It doubtless occurs in all of the New England States. The long-winged form, while not common, can scarcely be called rare. $2 \delta, 7 \uparrow$, specimens were taken in each case in company with the usual form. I have also an additional $\delta$ captured by Mr. C. J. Maynard at Newtonville, Mass., and Mr. Scudder has one from Iowa.

\section{Tryxalis Fabr. (= Metaleptea Brunner.)}

Truxalis Fabricius I775. S. Ent., p. 279 .

According to priority, as stated by Brunner himself (Revision, p. I 8 ), this name should be retained for this genus. The genus is out of place in Brunner's table since the apical angles of the hind femora are not produced.

Tryxalis brevicornis Linn. Figs. A, $\mathrm{Aa}, \mathrm{Ab}$.

Gryllus brevicornis. Linné, Cent. Ins. p. $15,37,-1763$.

Pyrgomorphabrevicornis. Thomas, 67. 
Pyrgomorpha punctipennis. Thomas, $68(?)$.

Truxalis brevicornis. Beutenmüller, 29 .

This species has been taken on Long Island in the near vicinity of New York by $\mathrm{Mr}$. Beutenmüller and will very likely be found in Conn. It will be readily determined by the characters given in the key. In coloration it is very similar to Dichromorpha viridis, the $\delta$ being either brown, or green above with dark brown sides, and the o either brown or green with a dusky line along the dorsal part of the sides of the pronotum which is continued on the head to the eye. It is found locally in the tall grass of swamps.

The following measurements are from Indiana specimens received from Prof. Blatchley.

Antenna. Hind fem. Teg. Teg. $>$ Hind fem. Body. Total

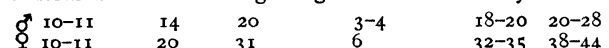

6. Dichromorpha gen. nov.

Type: Chloealtis viridis Scudd. The systematic position of this genus and its more important diagnostic characters have been indicated in Brunner's Revision under the name of Chloealtis (to which the type species has erroneously been referred), and to some extent in the preceding key. The type species is well described in Thomas, p. 75 .

\section{Dichromorpha viridis Scudd.}

Figs. 7, 7a, 7b.

Chloealtis viridis. Scudder, 455, -1862 .
Chloealtis viridis. Smith, Orth. Conn., 374. Fernald, 36. Morse, 14, 104. Beutenmüller, 292.

Chrysochraon viridis. Thomas, 75 .

Long-winged form, punctulata.

Chloealtis punctulata. Scudder, 455 .

Chloealtis punctulata. Fernald, 36 . "6 viridis var. punctulata.

Morse, 14, 105.

Chloealtis viridis var. punctulata. Beutenmüller, 292.

Chrysochraon punctulatum. Thomas, 77 .

Is not this Trux. angusticornis Stål. from S. Car. (Rec. orth., I06) ?

The chief points of interest to be noticed here concerning this species are those connected with its dimorphism in form and color. There is no doub that the punctulata form is but a case of reversion not uncommon in the female. I have yet to see a male with tegmina and wings reaching the end of the hind femora, that is to say, a true punctulata male, though a variation of 50 per cent. occurs in the length of the tegmina, these measuring 6 to $9 \mathrm{~mm}$. in length. The tegmina of the female are usually 8 to Io $\mathrm{mm}$. long, and of the reversional form i9 mm., but examples occur of intermediate length, one having them I $2 \mathrm{~mm}$. Contrary to what is usually stated both sexes are either green or brown above, but brown males are only about one-third as numerous as brown females. Of $330 \mathrm{~N}$. E. adults in my collection 20 are punctulata $\$, 5$ being 
brown and 15 green; 56 are brown viri-

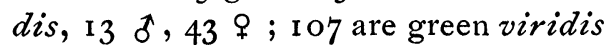
$q$, and the remaining 147 are green viridis 8 .

\begin{tabular}{|c|c|c|c|c|}
\hline $\begin{array}{l}\text { Antenna. } \\
\text { ơ } 6.5^{-8.5} \\
+7^{-8}-8\end{array}$ & $\begin{array}{l}\text { Hind fem. } \\
9.5-10.5 \\
14-15\end{array}$ & $\begin{array}{l}\text { Teg. } \\
6-9 \\
8-19\end{array}$ & $\begin{array}{c}\text { Teg. }<\text { H. fem. } \\
\begin{array}{c}4-5 \cdot 5 \\
\text { o-8 } \\
(7-8 \text { usually })\end{array}\end{array}$ & $\begin{array}{l}\text { Body } \\
1_{5}-16 \\
23-27\end{array}$ \\
\hline & $\begin{array}{c}\text { Body vs. } \mathrm{H} \\
0^{2}-2-2 \\
q-2-\end{array}$ & em. & $\begin{array}{l}\text { Total. } \\
\text { I1 } .5^{-15} \\
\text { 1 } 5.5^{-26.5}\end{array}$ & \\
\hline
\end{tabular}

This species is plentiful in southwestern New England in the latter half of the season, making its appearance late in July and continuing until late in autumn. The earliest date on which I have captured it is Aug. 4, at which time adults and young of both sexes were numerous. It is found in old pastures and mowing lands but prefers those of a damp and heavy character where the herbage is green throughout the season,- this is perhaps the rea- son of its more generally prevalent green coloration. In such situations I have found it numerous in individuals wherever taken. It is well protected by its coloration and is a decidedly sluggish insect, rarely using its wings, even when fully developed, in escaping its pursuers. It is found throughout Conn., in R. I., and in central and southwestern Mass. It is said by Scudder (Distrib. Insects N. H.) to have been taken in southern N. H., but this seems doubtful unless it possibly occurs there in the Connecticut Valley. I have taken it at Palmer, Mass.; Wickford, R. I. ; and in Conn. at Thompson, Montville, New Haven, Canaan, So. Kent, Stamford, and Greenwich, between the dates of Aug. 4 and 30. Judging from collections sent me by Prof. Fernald it is common at Amherst, Mass.

\title{
NOTES ON THE TYPES OF PAPIRIUS TEXENSIS PACK. AND DESCRIPTION OF A NEW SMYNTHURUS.
}

\author{
BY JUSTUS WATSON FOLSOM, CAMBRIDGE, MASS.
}

Upon examining Packard's types of $P$. texensis at the Museum of comparative zoölogy, the tube containing them was found to hold, not only fourteen specimens of a Papirius, but also ten examples of a Smynthurus, and the original description of $P$. texensis evidently combines the characters of both these species, which certainly do resemble each other superficially. It being necessary to separate the species in question, I have retained the original name for the Papirius, to which is applicable a large part of the original description, quoting this part below with a few supplement- aly notes, and have characterized the other species as $S$. packardii, again quoting where possible. The type specimens, considering they are nearly twenty-five years old, are well preserved, even in color.

Papirius texensis Pack. Pale luteous marbled with brown and black, head paler; a few short bristles above the mouth and on posterior dorsum; long stout hairs on vertex, anterior dorsum and sides of dentes. Eyes black. Antennae shorter than body, pale reddish brown, growing darker towards the end; segments nearly as I : $5: 5.5: 2$; basal segment twice as long as broad, naked; 

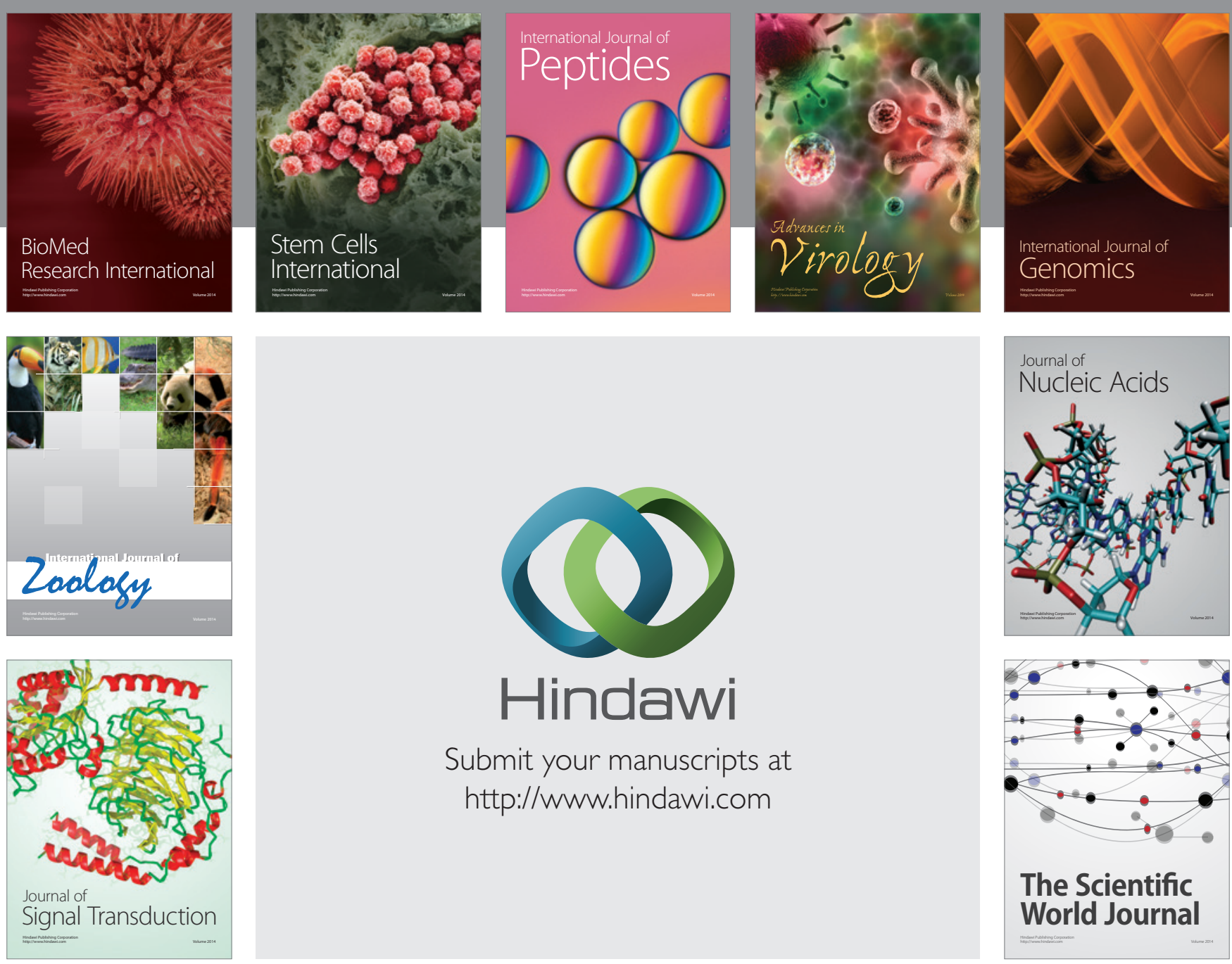

Submit your manuscripts at

http://www.hindawi.com
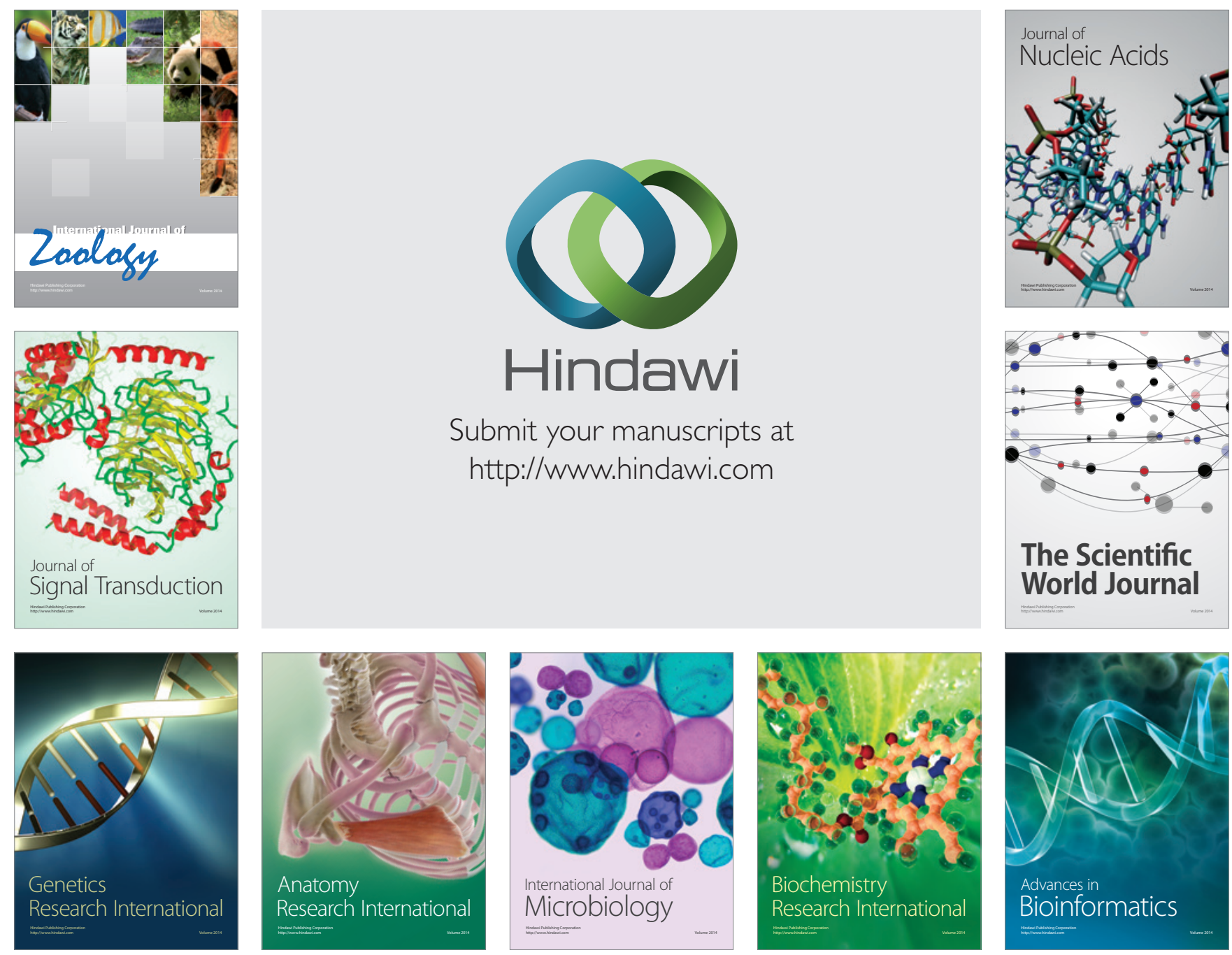

The Scientific World Journal
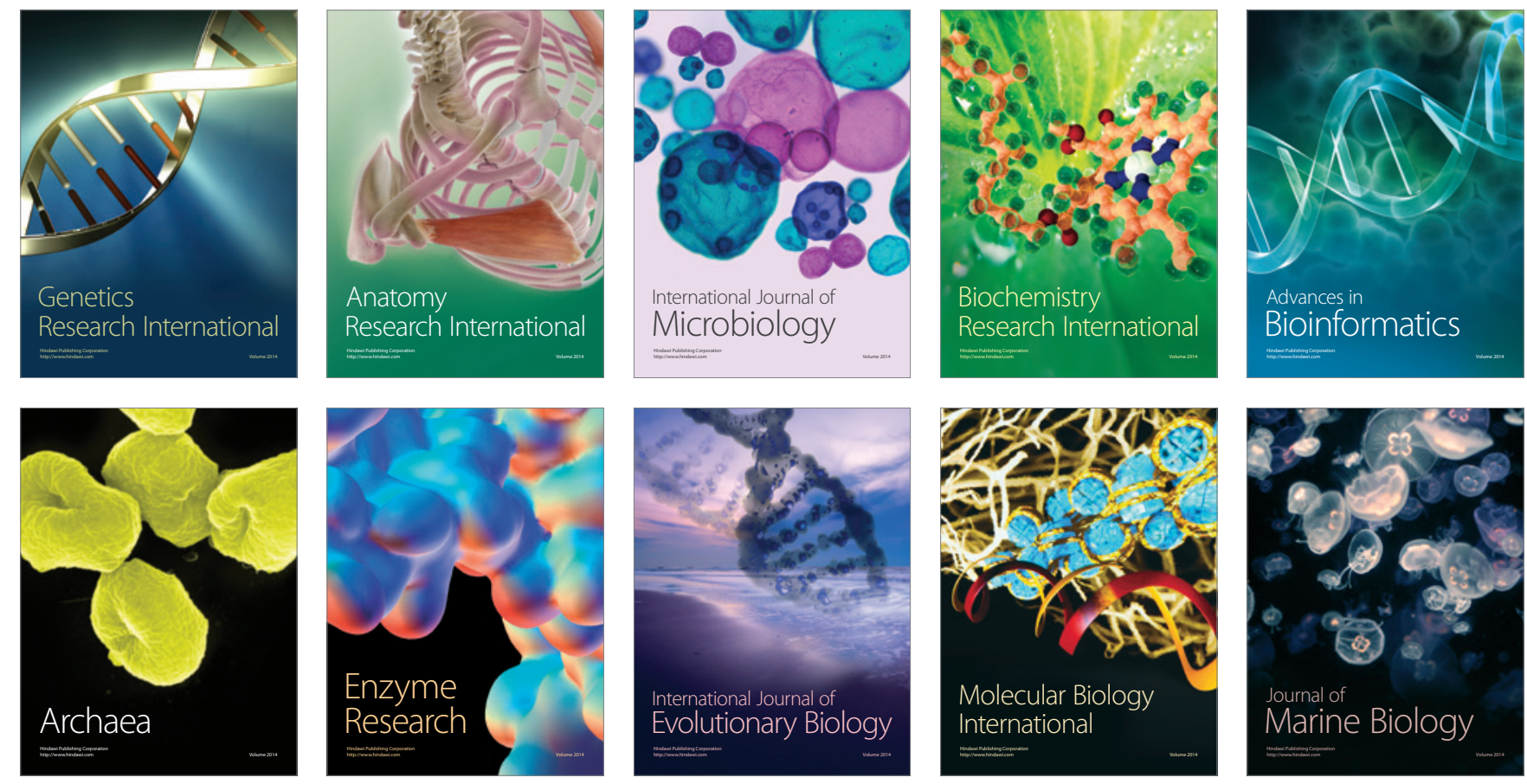